\title{
Urban Planning Capacity Development's Response to Emerging Towns: A Case Study of Wa in the Upper West Region of Ghana
}

\author{
Bernad Afiik Akanpabadai Akanbang, \\ Department of Planning, University for Development \\ Studies, UPW3, Wa Campus, Wa, UWR, Ghana \\ E-mail: bakanbang@uds.edu.gh / akanbang@yahoo.com \\ Mohammed Sulemana \\ Department of Governance and Development Management, \\ University for Development Studies \\ P.O.Box TL 1123, Tamale, Ghana \\ E-mail: mohammedsule88@yahoo.co.uk \\ Bashiru Yachori \\ Department of Governance and Development Management, \\ University for Development Studies,UPW3, Wa Campus, Wa, UWR, Ghana \\ E-mail: yachoribashiru@gmail.com \\ DOI//http://dx.doi.org/10.4314/gjds.v15i2.5
}

\begin{abstract}
The role of urban planning capacity development in ensuring that cities are engines of growth and development in Africa cannot be downplayed. However, limited research has examined how urban planning capacity development is responding to urbanisation in emerging cities. Using mainly data gathered from key informants and analysis of relevant documents, the study found that curative plans were increasingly used to compliment master plans in the effort to improve upon inner cities development. Google earth, satellite imagery, remote sensing, and aerial photography were also increasingly employed in the preparation of planning schemes. These developments notwithstanding, capacity development was still weak because the various dimensions of capacity development were not consciously developed as an integrated system. Conflicting planning legislation; inadequate funding; inadequate technical skills due to limited investment in technology for the training of planning professionals; and poor institutional collaboration exemplified the weaknesses in capacity development. In conclusion, capacity development for urban
\end{abstract}


planning was weak in all aspects, especially in legislation. In order to derive maximum benefit from the potentials of urbanisation, it is recommended that, a well-thoughtout plan should be fashioned to comprehensively address urban planning capacity development.

Keywords: Urbanisation, Urban Planning, Capacity Development, Institutional Development, Organisational Development, Human Resource Development

\section{Introduction}

Urbanisation has been one of the most significant processes in the transformation of societies. Its agglomeration effects offer advantages including; a large pool of labour, a greater local market, easier access to suppliers and specialised services, lower information and transaction costs, and more diversified contact networks (United Nations Economic Commission for Africa, n.d). However, how to manage urbanisation especially the use of urban land in a way that enables emerging towns to serve as engines of growth is a major challenge in many Sub-Saharan African countries. Besides, Africa's urbanisation unlike what happened in the Western Economies is without industrialisation (Goodfellow, 2017; Gollin, Jedwab \& Dietrich, 2016). If urbanisation is not adequately managed, it creates land use problems as: rise in slums and squatter settlements, poor sanitation, traffic jams, conflicts, rising youth unemployment and inadequate access to utility services among others (Melic, 2017; Mutiara et al., 2008 \& Larbi, 1996).

There is thus the need to search for ways of enabling Africa to maximise the benefits associated with urbanisation. Urban planning has over the years enabled urban towns to maximise their potential especially in most advanced countries. Similarly, capacity development is crucial to urban planning's ability to harness the potential of urbanisation for accelerated development. This paper contributes to the discourse of maximising the benefits of urbanisation for self-sustaining development of emerging urban towns through exploring capacity development of urban planning agencies in Wa, an emerging town in Ghana, West Africa. Wa is the capital town of the Upper West Region as well as the Wa Municipality. Wa was selected for the study because of its phenomenal urban growth in population and space, thus making it suitable for study. Urban land in Wa increased by 5.73 timesfrom $5.75 \mathrm{~km}^{2}$ in 1986 to $32.93 \mathrm{~km} 2$ in 2016 with an annual growth rate of 5.9\% (Korah, Nunbogu \& Akanbang, 2018). The total urbanised population of 71,051 in 2010 constituted $66.3 \%$ of the Municipality's total population, which is above the national urbanised share of $50.9 \%$ and the regional share of $16.3 \%$ (GSS, 2012). The total population of Wa Township was about 124479 as at 2016 (Korah, Nubogu \& 
Akanbang, 2018). The Municipality is also reported as having an urban population growth rate of $4 \%$ as compared to the national urban growth rate of $3.4 \%$ (GSS, 2005; GSS, 2010). The rapid growth in the urban population of Wa is associated with its upgrading as a regional capital and a municipality. The establishment of the Wa Campus of the University for Development Studies, as well as the Wa Polytechnic has added impetus to the growth of Wa.

In this paper, the definition of urban planning by Keeble (1969) and the Swedish International Development Agency (n.d) are adapted. The study defines urban planning as a process through which controlling and enabling tools are used to order the use of space in human settlements in a way that facilitates economic efficiency, convenience, sound environmental quality and aesthetic beauty and enables urban settlements and cities to serve a critical role as engines of growth and development. The definition of capacity development by Organisation for Economic Cooperation and Development (OECD) (2006) and Sanz, Wehn and Alaerts (2013) is also adapted for the study. Thus, Capacity development is defined in the study as the process by which individuals, groups, organisations, institutions and societies increase their abilities to perform core functions, solve problems, define and achieve objectives; and understand and deal with their developments in a broad context and in a sustainable manner.

Urbanisation at the global level is expected to hit $70 \%$ by 2050 with Africa and Asia being projected as the regions that will experience the largest growth in urban populations (United Nations, 2008). Ghana is one of the rapidly urbanising countries in Africa. The proportion of the country's population living in urban settlements, officially defined as any settlement with at least 5,00o people, has increased rapidly over the years. The number of urban settlements increased from $23 \%$ in 1960 to $51 \%$ in 2012 and is projected to increase to $62.9 \%$ by 2025 . In 1960 , Ghana had an urban population of about 1.6 million, constituting $23.1 \%$ of the total population. This more than doubled to 3.9 million in 1984, then to 8.3 million in 2000, and to 12.5 million in 2010. The average growth rate of the urban population between 1960 and 1970 was $4.7 \%$. This decreased to $3.3 \%$ during 1970 to 1984 but increased again to $4.6 \%$ between 1984 and 200o, and 4.2\% between 2000 and 2010 (Ghana Statistical Service, 2010). The level of urbanisation varies from region to region in Ghana. The national capital Greater Accra has the highest proportion of urban population ( $90.5 \%$ p), followed by Ashanti (6o.6\%) while the Upper West Region, the region under study has the lowest proportion of urban population (16.3\%).

Since Ghana embarked on decentralised governance in 1988, the number of districts have increased tremendously from 110 in 1988 to the current 216. The 
creation of the district capitals has attracted people into these towns and has changed the structure of these towns. The sharp increase in population numbers and the resulting uncontrolled settlements in these new urban towns pose considerable problems for their management (Ebert, 200o). Consequently, these towns are not able to appropriately fulfill their functions as local administrative and delivery centers, as well as decentralised poles of development (Ebert, 2000). Rapid urbanisation has therefore been characterised by mass unemployment, environmental degradation, poor housing and rising crime rates (National Development Planning Commission, 2008).This calls for serious urban planning and management practices otherwise Ghana cannot exploit the benefits of urbanisation to its fullest.

While effective urban planning and implementation remains the antidote to achieving sustainable city development in the mist of population growth (Asamoah, 2010; Ballaney, 2008; Masukazu, 2003; Mutiara 2008; SIDA, n.d), not much research work has gone into exploring how the capacity of urban planning agencies are being developed to respond to the rapid growth of urbanisation the Sub-Saharan Africa is witnessing. With respect to Ghana, in spite of the increasing numbers of towns that have become urbanised, most studies have only examined urban planning from the perspective of the large cities such as Accra, Kumasi, Takoradi and Tema (Asamoah, 2010; Ubink \& Quan, 2008; Yeboah 2003; 2006; Gough \& Yankson, 200o). Little research has gone into examining how urban planning is responding to the emergence of small towns in Ghana, even though, it is recognised that without adequate capacity, urban planning goals at the national, regional, and district levels cannot be realised.

\section{Evolution and Dimensions of Capacity Development in Urban Planning}

Urban planning capacity development has generally evolved from a narrow perception as transfer of skills usually from the North to the South to its current conception in which South -South and triangular cooperation in support of organisational development and management is emphasised (Pearson, 2011b). Three dimensions of capacity development - intangible or soft elements of capacity, adaptive capacity of organisations (Alaerts \& Kaspersma, 20o9; Ortiz \& Taylor, 2009), and policy or enabling environment or political dimension is recognised (Alaerts \& Kaspersma, 2009; Ortiz \& Taylor, 2009; Europe Aid, 2009). These dimensions of capacity development have been common in urban planning in Africa at different times since the 1960s. 
Capacity development practices in the 1960s and 1970s in urban planning were focused on empowerment of the individual through initiatives of foreign organisations. These were mostly visible in mass housing, slum clearance and urban renewal initiatives, which were generally driven by the belief that architecture and urbanism could promote development and shape social relations (Beeckmans, 2017; Fiori \& Brandao, 2007; Tyrrell, 2008). This period also marked the modernist view of urban development which relied on bringing change in cities through formal overlay of a set of spatial rules rather than comprehensively understanding existing conditions of cities. In terms of capacity development, people in key positions identified to undertake specialised projects were given training, skills, equipment and extra manpower to perform to a standard defined by usually the foreign organisation facilitating the capacity development.

This form of capacity development had little impact on building the capacity of organisations and creating the requisite enabling environment in terms of policy and legal framework for individuals to put to use the new skills they acquired. Thus, in spite of infrastructural improvements, the spatial dimensions of the city, witnessed insignificant improvements. Consequently, in the 1980s, the focus of capacity development went beyond the individual to encompass the structure, processes and procedures of the organisations that individuals worked in. Teskey (2005:4) captures succinctly the focus of capacity development in this period in the following: 'It is organisations that have capacity. Individuals have skills and competencies'. There was also a move away from physical projects in urban development to emphasising on strategic planning. As stated by Fiori and Brandao (2007:6), 'there was a growing fascination in the emerging discourse of 'strategic planning' which, superseding physical master planning methods (of the modernists), aimed at setting up institutional structures for the formulation of strategic visions of competitive cities in a 'globalised' market.' By the 1990s, it was becoming clearer that only when the individuals, organisations and institutions were aligned, would there be the possibility of truly sustainable capacity development (Teskey 2005:8). In the contemporary era, the focus on good governance as a build-up on efforts made on individual, organisational and institutional levels has become paramount. Thus capacity building today encompasses enhancements of the capacity of the public, private and civil society sectors; thus a move away from piecemeal interventions to deeper consideration of broader systemic capacity development (Boesen \& Thirlikdsen 2004:1). This present conceptualisation of capacity development recognises that the capacity of individuals, organisations, institutions and societies are nested within each other and co-influenced one another. Capacity development is thus viewed as being concerned about creating skills development, an enabling environment and agreed 
work practice in line with Dureau (2005). Figure 1 shows the various dimensions of capacity development and how they influence one another. The underlying theory of the framework is that, with good policies and legislation in place, organisational structure of the urban planning agencies would be well structured and the right people would be recruited and regularly trained to enable them to perform their functions effectively and efficiently. Thus, to enhance urban planning at any given point, the three dimensions of capacity development - individual, organisation and policy must all function effectively.

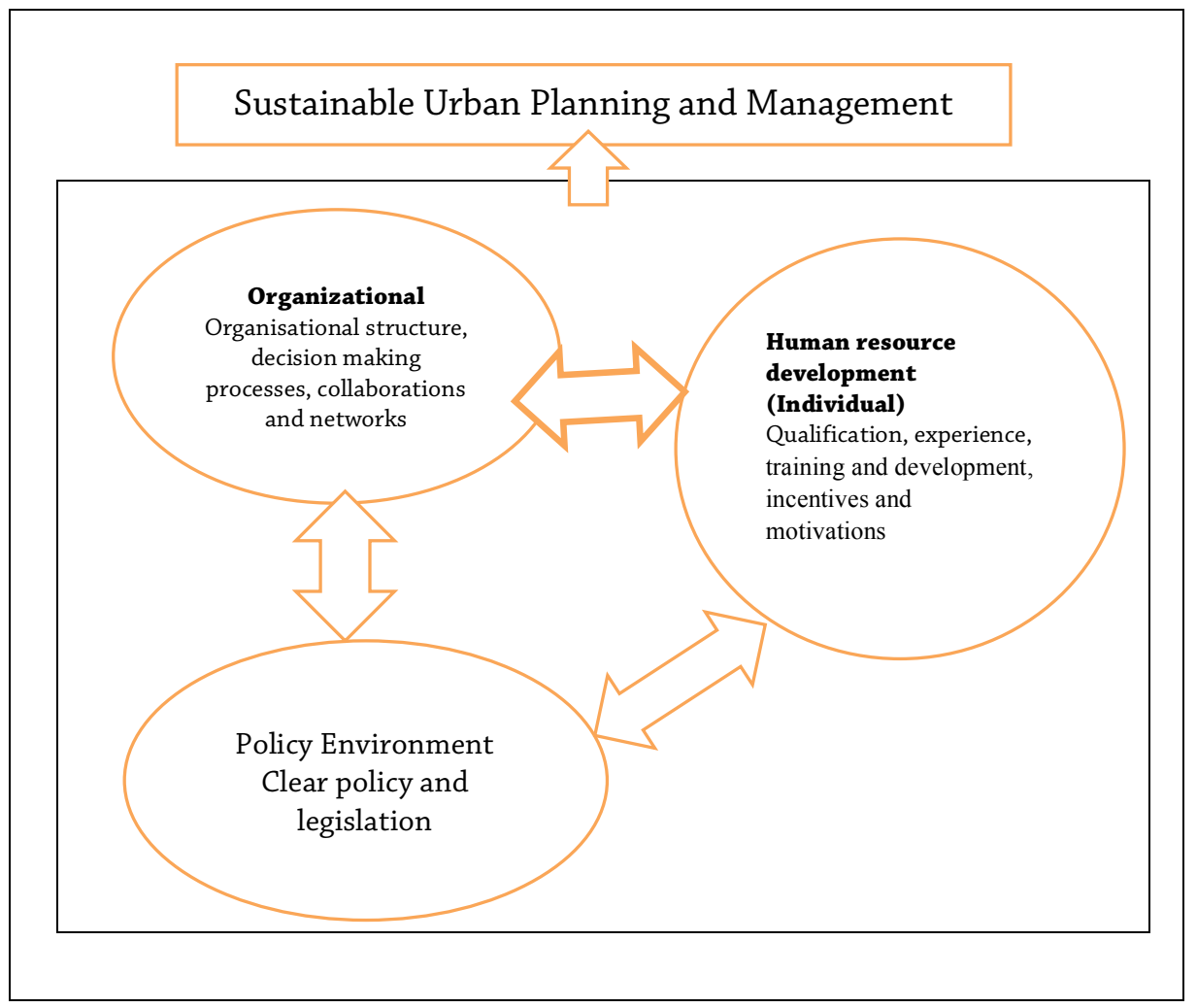

Figure 1: Conceptual framework

Source: Authors' Construct, 2016

\section{Methods}

A case study design was employed for the study. The rationale for the choice of case study was to explore deep into the subject of urban planning capacity development with a focus on limited key individuals and staff who have responsibility for urban planning in the municipality (Yin, 2004). It was also to enable the study gain a 
comprehensive perspective on the subject since case study is a multi-method that allows the use of a combination of methods including documents analysis, key informant interviews and observation in the collection of data (Creswell, 2009). Purposive sampling was used to select staff of urban planning and management institutions within the Wa Municipal and at the regional and national levels for data collection. These institutions were: the Planning Department of the University for Development Studies (UDS), the Planning Department of the Kwame Nkrumah University of Science and Technology (KNUST), Municipal Planning and Coordinating Unit (MPCU), Town and Country Planning Department (TCPD) at the Municipal, Regional and National levels, Building Inspectorate Unit (BIU) at the Municipal level, and the Land Commission and Environmental Protection Agency at the regional level. All heads of these departments were purposively selected for interview because they had specialised knowledge on the subject under study. Consequently, no specific sampling distribution approach was used to select respondents for interview. In all Twenty-three (23) respondents were interviewed.

Key Informant Interview was used to solicit in-depth information on issues as: curricula of planning capacity building institutions; strengths and weaknesses of urban planning legislations, trends in approaches to urban planning; conditions of service of staff; among others. Observation was used to collect information on office space, office equipment, and physical conditions of the built environment among others. Population census reports, conditions of service, curricula of planning programmes run in the Universities, and project reports were documents reviewed as part of the data collection process. Since a major part of the data collected was qualitative, data was categorised into themes based upon major issues explored in the study and contently analysed.

\section{Results}

\section{Institutional Development for Urban Planning}

Urban planning was underpinned by the Town and Country Planning Ordinance, 1945 (Code of Administrative Procedure (CAP) 84, which is a legacy of colonial government. Recent legislation such as Act 462 of 1993, though did not particularly address urban planning, has created grey areas in terms of roles in urban planning. For instance, the Town and Country Planning Department Ordinance 1945 (CAP 84) which established the Department of Town and Country Planning assigned the Department the function of designating an area as planning area; preparation and approval of schemes; execution of schemes and compensation and betterment. These functions duplicate with the Local Government Act, 1993, Act 462, which 
delineates MMDAs as planning authorities. A similar duplicated role is where Act 462 provides for the approval of plans by the Assembly while CAP 84 provides that this should be done by the Minister in charge of Town Planning. Staff of the TCPD expressed discomfort working under the uncoordinated legislations because they create situations for developers to frustrate the efforts of local planning authorities in their stab to manage physical development.

The Town and Country Planning Ordinance, 1945 [Code of Administrative Procedure (CAP) 84], the legislation governing the acquisition of permits for development was unrealistic. It requires that good titles should be endorsed by the Regional Registrar who is the land commissioner as a necessary condition for receiving a permit to undertake development. Considering that there were eleven (11) districts in the Upper West Region being served by the land commissioner; there were practical challenges in relation to traveling to the regional level in order to acquire good title to enable one to acquire a permit to develop. As one planning officer said, the requirements for good title acquisition and permitting can be scary and intimidating'. Another officer noted: "the requirements in practical sense make it very difficult for people to come to us for permit before development'. The Town and Country Planning Ordinance, 1945 (CAP) 84, needs to be repealed. I do not think making permitting conditional on good title is good under our circumstances". Another respondent also had this to say: "As a country, we need to rethink our planning. How can we still be using town and country planning laws and ordinances which were enacted in 1945 ? These laws are practically very limited in terms of their usefulness in our modern life".

The National Building Regulation, 1996 (LI 1630) specifies building materials requirements, alignment and utility lines specifications in order to regulate developments in towns and cities. The LI 1630, however, is not up-to-date with recent developments in cities such as the erection of cellular masks among others. The National Development Planning Commission (NDPC) Act, Act 479, which established NDPC as a central planning agency also appears biased towards economic policy; with spatial issues being relegated to the background. Similarly, the Local Government Act, 1993 (Act 462) grants MMDAs the power to demolish unauthorised physical developments, Section 9 of the National Building Regulations (LI 1630) gives a developer the power to proceed with development where approval for development is not given within three (3) months of the date of application. This provision makes it difficult for the cities to exercise development control functions.

Enforcement of building and planning regulations has been weak mainly because of political expediency. The following statement by a respondent shows why 
the assemblies were not capable of enforcing laws on building regulations. "The politician is only motivated by the desire to win or retain power which is a matter of vote. A nicely planned neighborhood does not vote but people who live in unapproved developments do. There is no chance for any planning proposal succeeding if our political leaders think it has the potential to affect their electoral fortunes".

Significant policy interventions in response to urban planning needs were: the implementation of the Land Administration Project (LAP) 1 \& 2; the drafting of a framework for spatial planning; the development of an urban policy; and the development of the land policy.

The Land Administration Project (LAP I \& II) started in 2003 with the objective of addressing issues such as urban upgrading and land use planning. Some mile stones achieved by the project include: the development of a computerised land information system for land sector agencies; enhanced coordination and collaboration among the major stakeholders in the land sector - the Lands Commission, Survey Department, Land Evaluation Board, Lands Title Registry, Office of the Stool Lands and Town and Country Planning Department.

The National Urban Policy (NUP) was launched in 2013. The Policy seeks to "promote a sustainable, spatially integrated and orderly development of urban settlements with adequate housing and services, efficient institutions, sound living and working environment for all people to support rapid socio-economic development of Ghana" (Ghana Statistical Service, 2010). A Spatial Development Framework (SDF) bill has been approved by Parliament in 2017. The framework profiles stakeholder consultations in the plan preparation process - at least three stakeholder consultation workshops during the plan preparation period should be held. The Land Use and Spatial Planning Authority (LUSPA) is expected to come out with a Long-Term National Spatial Development Plan in collaboration with the National Development Planning Commission at the national level. Regional SDFs would be prepared by the Regional Spatial Planning Committee (RSPC) which is answerable to the Regional Coordinating Council (RCC) and ratified by the NDPC. The District SDF would be prepared by the District Spatial Planning Committee (DSPC) for approval by the Assembly.

\section{Organisational Capacity Development}

The TCPD has in its period of existence since 1945 been anchored in seventeen ministries. The seemingly lack of permanent anchorage of the Department in a particular ministry has not helped to ensure stability in relationships in order to 
strengthen the organisational capacity of the Department. One respondent posed this rhetorical question as a show of his frustration with the transitional nature of the location of the Department in sector ministries: "Does it mean that the TCPD activities are related to all these different ministries? The Department should be autonomous or better still kept permanently under a ministry whose vision and policies are related to the Department's activities."

Role ambiguity among MMDAs and the TCPD was a feature of urban planning organisational capacity development. MMDAs under the Ministry for local governance and rural development have responsibilities in their jurisdictions for planning. However, they do not have the skills and technology to undertake urban planning. The TCPD which has the skills and technical capacity for urban planning is under the Ministry of Science and Technology.

The Department also works closely with the Lands Commission and its various divisions comprising the Survey and Mapping Division, Public and Vested Lands Management Division, Land Valuation Division, Land Title Registry Division and Office of the Administrator of Stools Lands. With reference to Survey and Mapping Division, its key role in planning is to prepare good and accurate base maps and do proper demarcations based upon which the TCPD can prepare their master, structure and site plans. However, surveyors and other staff of land commission are not present at the district level. Surveyors visit the districts only when the district needs them for special projects. This situation has led to the technical staff of Town and Country Planning Department assuming the role of surveyors in the demarcation of plots, and concomitantly the rise in land use problems as encroachment, overlapping plots among others. With respect to Land Title Registry Division, poor records keeping have resulted in double plot registration with different names.

Ineffective organisational collaborations meant a booming business for quack surveyors who collaborate with landlords to parcel out lands without making provision for public uses such as roads to unsuspecting tenants. The risk of this practice is that, if the landowners exhaust leasing all lands as cadastral plans, it becomes difficult to plan for the area without having to pay compensation to new landlords in order to make space for roads and other public infrastructures such as schools, hospitals and markets.

\section{Individual Capacity (Human Resource Development)}

It emerged that human capacity in terms of numbers and skills for urban planning is inadequate to respond to the rapid phenomena of urbanisation. 
These inadequacies cut across all the organisations with responsibilities in urban planning. A respondent's rendition of this problem is revealing: "We are four planners and two sub-professionals and seventeen technical staff who are responsible for the whole of the Upper West Region (UWR). We are responsible for 11 local planning authorities with a population of 576,583 people across a land size of about $18,478 \mathrm{~km}^{2}$. Under such conditions, how do you expect us to deliver planning services effectively?"

Moreover, only four of the eleven Municipal and District Assemblies have planning officers. Of these, only two districts are staffed by professional planners. The two professional planners are in Wa Municipal Assembly and Lawra District Assembly. The Municipal Planner has additional responsibility over Wa East and Wa West districts whereas the Lawra planner oversees the Nandom and Lanbussie Kane districts. The 11 districts currently put their staffing requirement at 24 . Thus the backlog of planners in the region stands at 20. The Wa Municipal TCPD had one professional planner and two technical officers. Municipal assemblies are supposed to have a minimum of four professional planners and a maximum of six whilst the district assemblies are required to have a minimum of two professional planners and a maximum of four. One of the respondents made the following observation with respect to the staffing situation of the Department: 'Ghana's population is fast growing but the number of planners keeps shrinking. Those who are retiring, dying, and resigning are not being replaced. The result is there for us all to see. If nothing is done urgently, Ghana will be left with no planners in the next few years'.

In terms of number of surveyors, the entire Upper West Region has only eight licensed surveyors. The other eight are not licensed. The building inspectorate unit also has only one Geodetic Engineer and two Building Inspectors at the Wa Municipal Assembly.

It came to light that opportunities and incentives for career development were limited. In the case of the TCPD, because the Department is not autonomous, it does not have a budget of its own from which they could allocate funds for the capacity development of staff. The study also found that staff who advanced in their career through further studies to build their capacity were not being rewarded. Two respondents had these to say on promotions in the TCPD: "I completed a master's programme three years ago but have since not been promoted, even though, I am due for promotion". "Some of us have been due for promotion over the past eight years and have still not been promoted. The issue is that, although we are under the Ministry of Science, Environment and Technology, it is the Head of Civil Service that recruits us and therefore have the mandate to conduct promotional interviews, which the service has not been doing". 
The study also found that the TCPDs were poorly resourced. Although they generate considerable revenue through permit application fees and other charges, the funds generated go to the MMDAs. The existing arrangement where the Department should get their funding from two sources - MMDAs and their mother ministry, Ministry of Science and Technology, results in at times no funding at all; as there is no clear line of activities each of the sources are supposed to fund. One of the respondents made the following observation concerning funding of the activities of the Department. "We do not have any budgetary allocations from our parent ministry. If you submit your budget to the district and you are lucky, you get between $15-20 \%$ of the amount requested. Without funds, we are like a car without fuel. That is why we have almost grinded to a halt". Another respondent also had this to say: "The only time district assemblies release funds is when they are embarking on physical projects that require documentations such as site plans and building permits". Table 1 shows the annual allocations from the parent ministry to the Department.

Table 1: Annual allocations received by the TCPD in Wa Municipal

\begin{tabular}{|l|l|l|l|}
\hline Year & Amount (GH)) & Exchange rate Ghc to the US \$ & Equivalent in US \$ \\
\hline 2011 & $2,389.40$ & 1.64 & 1457 \\
\hline 2012 & $5,690.00$ & 1.90 & 2995 \\
\hline 2013 & $6,001.90$ & 2.37 & 2532 \\
\hline 2014 & $8,439.20$ & 3.19 & 2646 \\
\hline 2015 & $3,457.00$ & 3.81 & 907 \\
\hline
\end{tabular}

Source: Wa Municipal Town and Country Planning Department, 2016

Under such funding constraints, it is not surprising that it was found that the Department was afflicted with the problem of inadequate logistics in terms of vehicles (only one vehicle at regional level), well equipped offices and studios with the necessary equipment as computers installed with appropriate Geographic Information System (GIS) software, and satellite images.

\section{Emerging Strategies for Dealing with Uncontrolled Urban Development}

It emerged that curative planning was used to deal with unplanned neighborhoods (usually older parts of settlements whose existence predated planning). Curative planning takes into consideration existing developments in an area and tries to improve upon the development of the area through the creation of access roads, drainage systems and lines of utilities to enable people access their homes easily 
and also to enable utility providers such as GWCL, VRA among others to extend their services to residents. Curative planning usually does not involve large scale demolitions and compensations as is the case with most urban renewal programmes. However, some residents usually forfeit some meters of their plots for the exercise to be successful. Intensive community engagement is required for such an exercise to be successful.

Even though community participation in planning processes have long been recognised, it has not been fully translated into action when coming out with planning schemes to regulate urban development, especially in Ghana. In most cases, land owners were unaware that their lands have been zoned for certain uses. Under such a context, it becomes difficult for planning to achieve its objectives, especially under a fragmented land ownership system. To deal with this problem, the study found out that planning agencies were rediscovering the importance of citizen engagement in the planning process. Consequently, radio discussions, durbars and other stakeholder engagements were organised in order to make the citizenry appreciate and contribute to the realisation of the objectives of planning ensuring order in space, convenience, aesthetic beauty and economic efficiency.

The cost of preparing base maps which is a requirement for preparing layouts or planning schemes is colossal. As a result, many assemblies were reluctant to venture into the preparation of planning schemes for their settlements. Consequently, many settlements were without planning schemes. For settlements with schemes, new areas were usually not covered because the schemes were not updated. In order to avoid haphazard development of areas that do not have base maps for planning schemes to be prepared for them, the TCPD has adopted the use of Google earth and satellite images for preparing planning schemes/layouts. Even though, this approach is not without problems as it contravenes existing arrangements for urban planning, it is helping the Department to regulate development through facilitating the preparation of schemes without having to prepare base maps at a cheaper cost.

\section{Discussion}

\section{Integrated Approach to Capacity Development}

In recent times, calls have been made for the systems approach to capacity development to be adopted. This approach ensures that all the dimensions of capacity development are consciously taken into consideration. This is because of the recognition that each of the three dimensions namely individual, organisation and institution influence one another in significant ways (Boesen \& Thirlikdsen, 
2004; Dureau, 2005; Teskey, 2005). Thus, there is the need for urban capacity development in Ghana to be approached in an integrated manner so as to benefit maximally from capacity development interventions.

\section{Legislative Environment Conducive for Urban Planning}

As noted by Cheema (1987), a sound legal basis and policy are vital for effective planning as they determine the 'rules of the game' for interaction between and among organisations. Capacities at the level of the enabling environment include policies, legislation, power relations and social norms, all of which govern the mandates, priorities, modes of operation and civic engagement across different parts of society. It is widely recognised that weak legislation is one of the challenges affecting the effective implementation of policies, agreements, and standards. The evidence gathered support this view. One of the weaknesses in legislation is regulation. At the writing stage of our study, we found out that, a new law on urban planning; the Land Use and Spatial Planning Act, Act 925 of 2016 was passed to deal with all the issues of collaboration, institutional anchoring, recruitment, training and development, financing, and logistical issues affecting urban planning. The establishment of the Land Use and Spatial Planning Authority (LUSPA) as part of the new legislation on urban planning is expected to curb regulation as a weakness in the existing legislations. By this arrangement, the Land Use and Spatial Planning Authority is to hold MMDAs accountable for the implementation of planning standards and development control.

\section{Law Enforcement}

McAuslan (1985) long noted the need for appropriate legislations to be enforced if they are to serve their purposes. A good legislation should actually have in it modalities for enforcing it. Thus, the new Land Use and Spatial Planning Legislation recently passed and that transformed the name of the TCPD to LUSPA could be the solution to the issue of enforcement of laws on urban planning in the country. It is important to recognise that enforcement of building regulations is key to the creation of self-sustaining cities. Under the new arrangement, the new LUSPA is a regulatory authority over urban planning in the country. They have the power to sue MMDAs who do not comply with building regulations in the country. However, this can be possible if the Authority rises above the name change and live up to the task given to them to ensure that planning regulations are implemented to the letter. Similarly, the integration of TCPD into the MMDAs will ensure that the hitherto collaboration issues between the Department and the Building Inspectorate Unit (located within the MMDAs); resulting in inability 
to enforce controlled development are resolved. This merger will ensure that the TCPD and the Building Inspectorate Unit are able to work together to ensure building permits are issued immediately to applicants in line with Section 9 of the National Building Regulations (LI 1630); and that the BIU have access to all the information on building permits issued so that they can monitor to ensure compliance with building regulations in the MMDAs. This would ultimately avoid the situation where developers capitalise on the three months provision in Section 9 of the National Building Regulations (LI 1630) which gives developers the power to proceed with development when approval for development is not given within three months of the date of application.

\section{Institutional Coordination and Collaboration}

Globalisation is teaching organisation about the need to form networks, merge or collaborate if they are to remain effective. However, it appears many public sector organisations in Ghana are yet to appreciate this point (Akanbang, Dugle \& Yakubu, 2016). Most organisations fail to look at the spirit of the legislative instruments that established them, and therefore the need for collaborations. In order to deal with issues of mismatch, overlapping and duplication of mandates, there is the need for collaboration among the agencies involved in urban planning. If institutional collaboration is not effective, the practice of one organisation trying to outdo another will continue and will not insure benefits to urban planning. Mainly individuals in institutions become ultimate beneficiaries. Institutional collaboration is particularly needed between the TCPD and divisions of the land commission if the issue of proper land documentation and controlled development is to be achieved.

\section{Amendment of the Land Policy to Guide Urban Development}

The rapid pace of urbanisation has resulted in the continuous expansion of urban areas with minimal planning influences. In Ghana, the continuous creation of more district assemblies would continue to result in more towns becoming urbanised. Therefore, an appropriate land policy for urban management is needed to enable district assemblies to plan the urban fringes in anticipation of urban sprawl. Currently, the transformation of urban-fringe lands from peri-urban to urban uses usually takes place by the subdivision of separate landholdings, and is subject to the problems of scattered development and poor subdivision design. This further leads to backlogs in the provision of space for public utility and road, land shortages, excessive land speculation, and high land prices. The traditional practice of regulating urban growth through issuing development permits has proved to be inadequate for the purpose of ordering development. There is an urgent need 
to rethink the basis on which urban land policies are grounded. For planning to succeed, the state needs to exert significant control over the supply of land for development. A more active involvement of the district assemblies in the land delivery process is a prerequisite for effective management of urban growth.

\section{Technology Adoption}

Technological development is of great importance to urban planning and management. Technology has revolutionised urban planning generally. However, the use of technology in Ghana in urban planning and management leaves much to be desired. While in many advanced cities, planners are discussing and exploring technologies for cleaner cities such as the use of electric cars, we are still struggling to move away from analog base planning to digital base planning with the help of GIS Technology. To facilitate this transition to digital base planning, planning schools and institutes need to transform planning education. Planning studios should be equipped with modern equipment such as computers installed with GIS Software, digitizers, GPS equipment, Satellite images, Remote Sensing and Aerial Photography among others to expose students to these facilities so that they can help in the diffusion of technology. GIS should also be made a key component of planning education. There should also be investment in the establishment of modern studios for the offices of the TCPD at the MMDAs level to enable them make use of technology in the planning and management of cities, which has so far been a huge problem in Africa and the developing world generally.

\section{Conclusion and Recommendations}

The study concludes that capacity for urban planning in emerging cities is deficient in all dimensions of capacity development- skills, technology, legislation, and coordination. The result of the deficiencies is that city planners were managing development instead of leading development. As a consequence, uncontrolled developments were found in almost every available open space in the built-up areas leaving limited space for public services as roads, drainage and utility services. We recommend the strict implementation of the Act 925 of 2016 by all the agencies concerned. The Land Use and Spatial Planning Authority (LUSPA) should assert itself and ensure that MMDAs live by the planning and building regulations. There should also be rapid diffusion of technology through investment in technology at the level of training institutions and MMDA level in order to take advantage of technology to plan and manage our cities especially the emerging ones in ways that they are self-sustaining. There should be a policy that mandates MMDAs to prepare a four-years spatial development plan alongside the four-year DMTDP to enhance 
urban planning. It is also recommended that there should be an enhancement in the working conditions - attractive salary, requisite equipment to aid in their work, standardisation of promotion and study leave among others for urban planning staff in order to attract the requisite skills and personnel to the sector.

\section{References}

Akanbang, B.A.A., Dugle, G. and Yakubu, I. (2016). Evaluation inquiry in donor funded programmes in Northern Ghana. Ghana Journal of Development Studies, Vol. 13, No. 1, pp 18-40.

Alaerts, G. and Kaspersma, J.M. (2009). 'Progress and challenges in knowledge and capacity development' In M.W. Blokland, G.J. Alaerts, J.M. Kaspersma, M. Hare (eds)'Capacity development for improved water management' Edition: 1, Publisher: Taylor and Francis.

Asamoah, B. (2010). Urbanization and changing patterns of urban land use in Ghana. Policy and planning implications for residential land use in Kumasi. Unpublished MSc Dissertation, Department of Planning, KNUST.

Ballaney, S. (2008). The town planning scheme mechanism in Gujarat, India, The World Bank, Washington D.C.

Beeckmans, L. (2017) The development syndrome : post-war housing and residential segregation in French Dakar (Senegal): building and contesting the SICAP housing schemes in the late colonial period (1951-1960) Canadian Journal of African Studies.51(3). p.359-388.

Boesen, N and Therkildsen, O. (2004). Between naivety and cynicism: a pragmatic approach to capacity development. http://www.undg.org/docs/8947/UNDGCapacity-Assessment-User-Guide-Feb-2008-FINAL.doc.

Cheema, G. S. (1987) Urban shelter and services: public policies and management approaches New York, Praeger.

Creswell, J.W. (2009). Research Design Qualitative, Quantitative, and Mixed Methods Approaches; $3^{\text {rd }}$ Edition. London: SAGE Publications.

Dureau, C. (2005). Capacity building framework ACFID: Capacity building in development, emerging urban form in Accra, Ghana. Africa Today, Vol. 50, No. 1, pp. 107-119.

Ebert, F. (2000). Making a future for cities: Development policy in the urban century Federal Ministry for Economic Cooperation and Development, US, Press and Public Relations. 
Europe Aid (2009). Toolkit for capacity development, Brussels, available www. capacity4dev.eu.

Fiori, J. and Brandao, Z. (2007). Spatial strategies and urban social policy: urbanism and for DFID DFID Government and Social Development Group.

Ghana Statistical Service (GSS) (2012). 2010 Population and Housing Census. Report, Kumasi Metropolis. Accra: Ghana Statistical Service.

Ghana Statistical Service (2010). Ghana Population Data Analysis Report; SocioEconomic a Demographic Trends. Vol. 1, Accra: GSS.

Ghana statistical service (2005). Ghana Population Data Report Vol. 2. Accra: Ghana Statistical Service.

Gollin, D., Jedwab, R. and Dietrich, V. (2016). Urbanisation with and without industrialisation Journal of Economic Growth, Vol. 21 Issue1, pp. 35-70.

Goodfellow, T. (2017). Urban fortunes and skeleton cityscapes: real estate and late urbanisation in Kigali and Addis Ababa. International Journal of Urban and Regional Research, Vol. 41, Issue 5, pp. 786-803.

Gough, K. and Yankson, P. (2000). Land markets in African cities. the case of periurban Accra, Ghana Urban Studies, Vol. 37, No. 13, pp. 2485-2500.

Keeble, L. (1969). Principles and practice of town and country planning $4^{\text {th }}$ edition. London. Estate Gazette.

Korah, P.I., Nunbogu, A.M. and Akanbang, B.A.A. (2018). Spatio-temporal dynamics and livelihoods transformations in Wa, Ghana. Land Use Policy, Vol. 77, pp. $174-185$.

Larbi, W.O, (1996). Spatial planning and urban fragmentation in Accra, Third World Planning Review, Vol.18, No. 2, pp. 193-214.

Masukazu, I. (2003). Integrated land use planning; infrastructure and services. www.citeseerx.ist.psu.edu.

McAuslan, P. (1985). Urban land and shelter for the poor. London: Earthscan.

Melic, K. (2017). Capacity building with African Cities Centre for liveable cities, Singapore.

Mutiara, F. et al (2008). Managing Asia's rapid urbanization for social progress. Indonesia, 6th Hitachi Young Leaders Initiative.

National Development Planning Commission (2008). A National Strategy for Sustainable Human Settlements in Ghana Draft Report, Accra: Government of Ghana. 
Pearson, J. (2011b). Training and beyond: Seeking better practices for capacity development OECD Development Cooperation working papers.

Organisation for Economic Cooperation and Development (2006). The challenge of capacity development: Working towards good practice. DAC Network for Governance. OECD.

Ortiz, A. and Taylor, P. (2009). Learning purposefully in capacity development, why, what and when to measure? An Opinion paper prepared for IIEP. International Institute for Educational Planning, 7-9 rue Eugene Delaccroix, 75116, Paris, France.

Sanz, M.P., Veenstra, S. de Montalvo, U.W., Tulder, R.V. and Alaerts, G. (2013). What counts as 'results' in capacity development partnerships between water operators? A multi-path approach toward accountability, adaptation and learning Water Policy Vol 15 No 2 PP 242-266; DOI:10.2166/wp.2013.022.

Swedish International Development Agency (SIDA) (n.d). Urban development planning Urban Issue Paper Supplement to SIDA's policy for urban development Fighting Poverty in an Urban World. Swedish International Development Cooperation Agency SE-105 25 Stockholm Visits: Valhallavägen 191, www.sida.se sida@sida.se Urban Division: urban@sida.se • www.sida.se/ urban.

Teskey, G. (2005) Capacity Development and State Building: Issue, Evidence and Implications for DFID DFID Government and Social Development Group.

Tyrrell, M. L. (2008). Urban Design for Capacity Development in Informal Settlements Case Study: Diepsloot, Johannesburg, South Africa. Public Space and Environmental Infrastructure.

Ubink J.M. and Quan, J.F. (2008) How to combine tradition and modernity. Regulating customary land management in Ghana Land Use Policy, Vol. 25 pp. 198-213.

United Nations, (2008). World Urbanisation Prospects. The 2007 revision. New York; United Nations.

United Nations Economic Commission for Africa (UN ECA) ( n.d). United Nations Economic Commission for Africa high level policy dialogue on development planning in Africa concept note on the theme Integrating Urbanization in National Development: Planning in Africa 7-9 June 2016 Yaoundé, Cameroon Capacity Development Division (CDD) in collaboration with the Social Development Policy Division (SDPD).

Yeboah, I. (2003). Demographic and housing aspect of structural adjustment and emerging urban form in Accra, Ghana. Africa Today, Vol. 50, No. 1, pp. 107-119. 
Yeboah, I. (2006). Subaltern strategies and development practice: urban water privatisation in Ghana The Geographical Journal, Vol. 172, Issue 1 pp. 50-65.

Yin, R. K. (2004). Case study methods. Washington, DC: Cosmos Corporation. 